\title{
Long-term response to sulfonylurea in a patient with diabetes due to mutation in the KCNJ11 gene
}

\author{
Resposta a longo prazo com sulfonilureia em um paciente \\ com diabetes associado à mutação no gene KCNJ1 1
}

Marcio F. Vendramini', Lucimary C. Gurgel', Regina S. Moisés'

1 Division of Endocrinology, Universidade Federal de São Paulo (Unifesp), São Paulo, SP, Brazil

\author{
Correspondence to: \\ Regina S. Moisés \\ Universidade Federal de São Paulo, \\ Escola Paulista de Medicina, \\ Disciplina de Endocrinologia, \\ Rua Botucatu, 740, $2^{\circ}$ andar \\ 04034-970 - São Paulo, SP, Brazil \\ rmoises@unifesp.br
}

Received on Apr/22/2010 Accepted on Jul/7/2010

\begin{abstract}
Objective: To report the long-term (30-month) effect of the switch from insulin to sulfonylurea in a patient carrying the p.G53D (c.158G>A) mutation in KCNJ11 gene. Subject and method: A 29-year-old male patient was diagnosed with diabetes in the third month of life and after identification of a heterozygous p.G53D mutation in the KCNJ11 gene, the therapy was switched from insulin to sulfonylurea. Results: Long-term follow-up (30 months) showed that good metabolic control was maintained (HbA1c: $6.6 \%$ ) and the glibenclamide dose could be reduced. Conclusion: Long-term therapy with sulfonylureas in patients with neonatal diabetes due to mutation in the KCNJ11 gene is safe and promotes sustained improvement of glycemic control. Arq Bras Endocrinol Metab. 2010;54(8):682-4

Keywords

Neonatal diabetes; KCNJ11 mutation; sulfonylurea therapy
\end{abstract}

\section{RESUMO}

Objetivo: Reportar o efeito a longo prazo (30 meses) da substituição de insulina por sulfonilureia em um paciente com a mutação p.G53D (c.158G>A) no gene KCNJ11. Sujeito e método: Paciente do sexo masculino, atualmente com 29 anos de idade, foi diagnosticado com diabetes melito no terceiro mês de vida e, após identificação da mutação p.G53D (c.158G>A) em heterozigose no gene $K C N J 11$, a terapia foi substituída de insulina para sulfonilureia. Resultados: Seguimento a longo prazo (30 meses) mostrou que o bom controle metabólico foi mantido (HbA1c: 6,6\%) e a dose de glibenclamida pode ser reduzida. Conclusão: A terapia com sulfonilureia a longo prazo em pacientes com diabetes neonatal decorrente de mutações no gene KCNJ11 é segura e promove uma melhora persistente no controle metabólico. Arq Bras Endocrinol Metab. 2010;54(8):682-4

\section{Descritores}

Diabetes neonatal; mutação KCNJ11; terapia com sulfonilureia

\section{INTRODUCTION}

$\mathrm{N}$ eonatal diabetes mellitus is a rare condition characterized by hyperglycemia within the first months of life, which may either be permanent or transient. Activating mutations in the genes KCNJII and $A B C C 8$, which encode the two subunits Kir6.2 and SURl of the pancreatic ATP-sensitive potassium channel, are the most frequent cause of permanent neonatal diabetes (1-3). Approximately $30 \%$ of individuals with activating mutations in $K C N J 11$ have neurologic features in addition to neonatal diabetes $(4)$. The main neurologic findings are developmental delay, muscle weakness and epilepsy and this has been proposed to be part of a syndrome referred as DEND (developmental delay, epilepsy and neonatal diabetes) syndrome (5). A less severe form without epilepsy is called intermediate DEND syndrome.

Successful switch from insulin to sulfonylurea (SU) therapy has been reported in the majority of the patients with KCNJ11 mutations (6-8); however, there are few reports on the long-term efficacy and safety of this change (9-12).

Here we report the long-term (30-month) effect of the switch from insulin to sulfonylurea in a patient carrying the p.G53D mutation in the KCNJ11 gene. 


\section{PATIENT PRESENTATION}

The patient, who is currently 29 years of age, was diagnosed with diabetes in the third month of life during a ketoacidosis episode. Insulin treatment was initiated at that time and even on intensive insulin therapy, his glucose control was erratic with marked hyperglycemia. His growth curve was consistently along the $10^{\text {th }}$ percentile for height. During follow-up a delay in motor milestones was observed: the proband started walking autonomously only at 28 months. No muscle weakness or lower limb hypotonia was present. Crisis of generalized seizures started at age 5 during episodes of hypoglycemia, mainly in nocturnal period. His EEG was normal. He also showed severe learning difficulties and very poor attention and despite receiving special education little improvement was achieved.

At the age of 26 years, informed consent for genetic analysis was obtained from the proband's parents. A blood sample was obtained and genomic DNA was extracted from peripheral blood leukocytes using a commercial kit (Puregene DNA Isolation Kit, Gentra System, Minneapolis, MN, USA). The single exon of KCNJ11 was amplified by PCR in three overlapping fragments. The PCR products were directly sequenced with the use of Big Dye Terminator Cycle Sequencing Reaction Kit version 3.1 and analyzed on an ABI Prism 3100 Genetic Analyzer (Applied Biosystems, CA, USA). The proband was found to have a heterozygous change of guanine to adenine on nucleotide 158 , which resulted in glycine to aspartic acid substitution at codon 53 (p.G53D, c.158G>A mutation). Both parents were negative for this mutation. On the basis of the genotype and clinical features consisting of neonatal diabetes with developmental delay but not

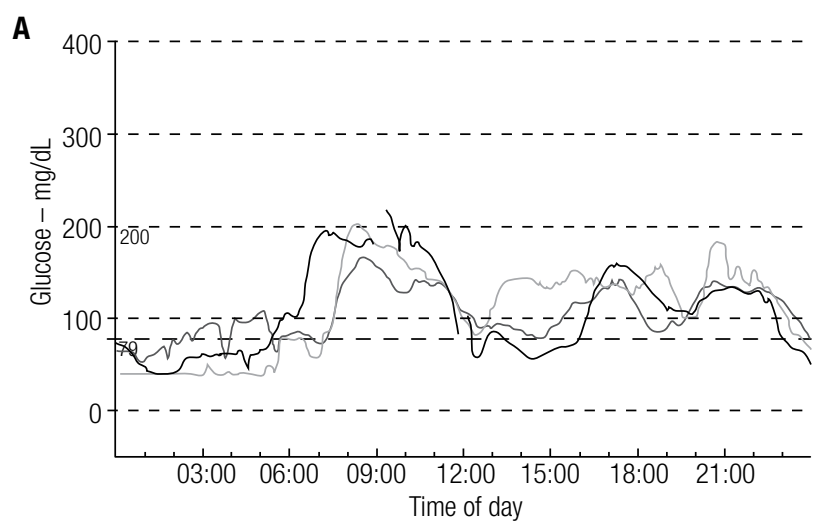

epilepsy, the patient was given a diagnosis of intermediate DEND syndrome. Following the identification of the mutation the patient was transferred from insulin to glibenclamide. The initial response to SU therapy was previously reported (13). After 4 weeks the patient was independent of insulin and using $0.8 \mathrm{mg} / \mathrm{kg} /$ day of glibenclamide divided into three doses. During the following 3 months, as the patient experienced mild hypoglycemic episodes, the glibenclamide dose was reduced to $0.68 \mathrm{mg} / \mathrm{kg} /$ day. A 72 -hour continuous glucose monitoring system (CGMS, Medtronic Minimed, Sylmar CA, USA) showed mean glucose of 108 $\mathrm{mg} / \mathrm{dL}$ with $71 \%$ of glycemic values between 80 and $200 \mathrm{mg} / \mathrm{dL}$ and $1 \%$ values above $200 \mathrm{mg} / \mathrm{dL}$ (Figure $1 \mathrm{~A})$. HbAlc levels reduced from $8.2 \%$ to $7.6 \% 3$ months after the transfer. A weight loss of $3.8 \mathrm{~kg}$ was observed in the first 8 weeks of SU therapy with subsequent weight stabilization. Currently, 30 months after the introduction of $\mathrm{SU}$, good metabolic control is maintained (HbAlc: 6.6\%) and the glibenclamide dose was reduced to $0.55 \mathrm{mg} / \mathrm{kg} /$ day. During the course of SU therapy no severe hypoglycemic episodes were reported. Another 72-hour continuous glucose monitoring was performed and showed mean glucose of 107 $\mathrm{mg} / \mathrm{dL}$ with $80 \%$ of glycemic values between 80 and $200 \mathrm{mg} / \mathrm{dL}$ and none above $200 \mathrm{mg} / \mathrm{dL}$ (Figura lB). Incipient diabetic nephropathy was diagnosed 9 years ago and therapy with ACE-inhibitors was initiated at that time. Fourteen months after the introducing SU, microalbuminuria in nocturnal collection of urine decreased from $77 \mathrm{ug} / \mathrm{min}$ to $32 \mathrm{ug} / \mathrm{min}$ and remained stable through the follow-up period.

The investigation was approved by the Ethics Committe of Escola Paulista de Medicina, Universidade Federal de São Paulo.

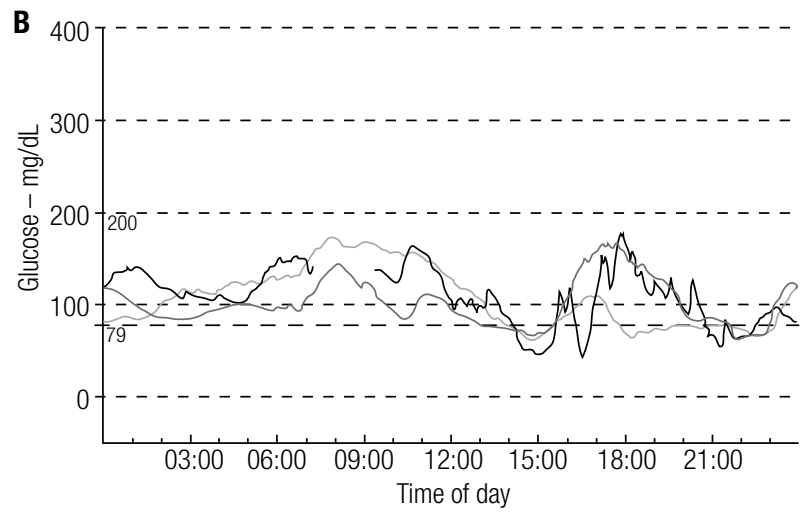

Figure 1. Glucose levels captured by the 72-h continuous glucose monitoring system 3 months (A) and 30 months (B) after switching from insulin to glibenclamide therapy. Each line represents a 24-h period. 


\section{DISCUSSION}

Activating mutations in the genes encoding the ATPsensitive potassium channel causes failure of this channel to close in response to increased intracellular ATP, thus inhibiting insulin secretion. However, sulfonylureas bind to the SURl subunit and close the ATPsensitive channel by an ATP-independent mechanism resulting in insulin release even in cells with activated mutations in KCNJ11 (14).

We describe herein a 30 -month experience of sulfonylurea treatment in an adult patient with intermediate DEND syndrome due to p.G53D mutation in KCNJ11. Following the transfer from insulin to SU we observed marked improvement in glycemic control that was maintained over the follow-up period, despite decreasing SU doses. No side effects were reported. The successful transfer to SU is consistent with the previous report of a patient with permanent neonatal diabetes carrying the same mutation (15). To examine the consequences of this mutation, Koster and cols. (15), coexpressed a mutant Kir6.2 subunit containing the p.G53D mutation with the wild-type SURI subunit. Channel activity in intact cells was screened by ${ }^{86} \mathrm{Rb}^{+}-$ efflux and ATP sensitivity was measured directly in excised membrane patches (15). The authors have demonstrated an increased channel activity and reduced ATP sensitivity by approximately 20 fold in homomeric channels.

There are few reports of chronic diabetes complications in patients with neonatal diabetes and the role of SU treatment in their evolution. Klupa and cols. (10) reported progression of a pre-existing diabetic retinopathy in a patient whose treatment was transferred from insulin to SU (10). Despite no causal relationship between the retinal changes and SU treatment could be proven, the authors recommend special ophthalmological attention in subjects with pre-existing advanced diabetic retinopathy. Our patient had no diabetic retinopathy when sulfonylurea was initiated and no evidence of this complication was found during the follow-up period. Reduction in microalbuminuria was observed during SU therapy possibly related to the improvement of metabolic control. Klupa and cols. (12) also observed some regression in the albumin/creatinine ratio in one patient.

In summary, this case illustrates that switching from insulin to sulfonylurea is safe and promotes sustained improvement of glycemic control on long-term follow-up.

Disclosure: no potential conflict of interest relevant to this article was reported.

\section{REFERENCES}

1. Gloyn AL, Pearson ER, Antcliff JF, Proks P, Bruining GJ, Slingerland AS, et al. Activating mutations in the gene encoding the ATP-sensitive potassium-channel subunit Kir6.2 and permanent neonatal diabetes. N Engl J Med. 2004;350(18):1838-49.

2. Flanagan SE, Edghill EL, Gloyn AL, Ellard S, Hattersley AT. Mutations in KCNJ11, which encodes Kir6.2, are a common cause of diabetes diagnosed in the first 6 months of life, with the phenotype determined by genotype. Diabetologia. 2006;49(6):1190-7.

3. Sagen JV, Raeder H, Hathout E, Shehadeh N, Gudmundsson K, Baevre $\mathrm{H}$, et al. Permanent neonatal diabetes due to mutations in KCNJ11 encoding Kir6.2: patient characteristics and initial response to sulfonylurea therapy. Diabetes. 2004;53(10):2713-8.

4. Proks P, Antcliff JF, Lippiat J, Gloyn AL, Hattersley AT, Ashcroft FM. Molecular basis of Kir6.2 mutations associated with neonatal diabetes or neonatal diabetes plus neurological features. Proc Natl Acad Sci USA. 2004;101(50):17539-44.

5. Hattersley AT, Ashcroft FM. Activating mutations in Kir6.2 and neonatal diabetes. New Clinical Syndromes, New Scientific Insights, and NewTherapy. Diabetes. 2005;54(9): 2503-13.

6. Pearson ER, Flechtner I, Njolstad PR, Malecki MT, Flanagan SE, Larkin $B$, et al. Switching from insulin to oral sulfonylureas in patients with diabetes due to Kir6.2 mutations. N Engl J Med. 2006;355(5):467-77.

7. Tonini G, Bizzarri C, Bonfanti R, Vanelli M, Cerutti F, Faleschini E, et al. Sulfonylurea treatment outweighs insulin therapy in shortterm metabolic control of patients with permanent neonatal diabetes due to activating mutations of the KCNJ11 (Kir 6.2) gene. Diabetologia. 2006;49(9):2210-3.

8. Stanik J, Gasperikova D, Paskova M, Barak L, Javorkova J, Jancova $E$, et al. Prevalence of permanent neonatal diabetes in Slovakia and successful replacement of insulin with sulfonylurea therapy in KCNJ11 and ABCC8 mutation carriers. J Clin Endocrinol Metab. 2007;92(4):1276-82.

9. Wagner VM, Kremke B, Hiort O, Flanagan SE, Pearson ER. Transition from insulin to sulfonylurea in a child with diabetes due to a mutation in KCNJ11 encoding Kir6.2 - initial and long-term response to sulfonylurea therapy. Eur J Pediatr. 2009;168(3):359-61.

10. Klupa T, Skupien J, Mirkiewicz-Sieradzka B, Gach A, Noczynska $A$, Szalecki $M$, et al. Diabetic retinopathy in permanent neonatal diabetes due to Kir6. 2 gene mutations: the results of a minimum 2-year follow-up after the transfer from insulin to sulphonylurea. Diabet Med. 2009;26(6):659-64.

11. Begum-Hasan J, Polychronakos C, Brill H. Familial permanent neonatal diabetes with KCNJ11 mutation and the response to glyburide therapy-a three-year follow-up. J Pediatr Endocrinol Metab. 2008;21(9):895-903.

12. Klupa T, Skupien J, Mirkiewicz-Sieradzka B, Gach A, Noczynska A, Zubkiewicz-Kucharska $A$, et al. Efficacy and safety of sulfonylurea use in permanent neonatal diabetes due to KCNJ11 gene mutations: 34-month median follow-up. DiabetesTechnolTher. 2010;12(5):387-91.

13. Gurgel LC, Crispim F, Noffs MH, Belzunces E, Rahal MA, Moisés RS. Sulfonylurea treatment in permanent neonatal diabetes due to G53D mutation in the KCNJ11 gene: improvement in glycemic control and neurological function. Diabetes Care. 2007;30(11):e108.

14. Koster JC, Remedi MS, Dao C, Nichols CG. ATP and sulfonylurea sensitivity of mutant ATP-sensitive $\mathrm{K}+$ channels in neonatal diabetes: implications for pharmacogenomic therapy. Diabetes. 2005;54(9):2645-54.

15. Koster JC, Cadario F, Peruzzi C, Colombo C, Nichols CG, Barbetti F. The G53D mutation in Kir6.2 (KCNJ11) is associated with neonatal diabetes and motor dysfunction in adulthood that is improved with sulfonylurea therapy. J Clin Endocrinol Metab. 2008;93(3):1054-61. 